DOI: $10.31866 / 2410-1176.45 .2021 .247373$

УДК 781.22:534.843.2"20"

\section{ПРИЙОМИ ВИКОРИСТАННЯ ШТУЧНОЇ РЕВЕРБЕРАЦЇ̈ У СУЧАСНІЙ ЗВУКОРЕЖИСУРІ}

\author{
Корякін Олексій Олексійович \\ Кандидат педагогічних наук, старший викладач, \\ ORCID: 0000-0002-3084-8796, \\ e-mail: profextreme@i.ua, \\ Сумський державний педагогічний університет \\ імені А. С. Макаренка, \\ вул. Герасима Кондратьєва, буд. 134, Суми, Украӥна, 40021
}

Мета статті полягає в систематизації основних сучасних прийомів використання реверберації у звукорежисурі. Для реалізації мети використано методи: системно-аналітичний, мистецтвознавчий та порівняльно-історичний. Наукова новизна полягає в уточненні класифікації та систематизації основних сучасних прийомів використання штучної реверберації, а також опануванні методичних засад штучної реверберації в процесі професійної підготовки. Основні результати і висновки дослідження. Еволюція цифрових технологій у галузі звукорежисури, запровадження ревербераційних алгоритмів сприяли активному використанню штучної реверберації, зокрема «згорткової» реверберації із найсучаснішим ревербераційним алгоритмом. У статті розглянуто прийоми штучної реверберації для створення звукової перспективи; для оброблення back-вокалу та дилею; для «пом’якшення» звучання певних партій музичних інструментів; для опрацювання різних однотипних сигналів; для оброблення партії соло $з$ двома ефектами реверберації. Певні різновиди штучної реверберації використовувалися на різних етапах розвитку музичної індустрії. Сучасний стан розвитку програмного забезпечення дає змогу використовувати відразу декілька алгоритмів реверберації і створювати оригінальне звучання. Засвоєння здобувачами вищої освіти прийомів штучної реверберації доцільно розпочати з найпростіших ефектів із незначним варіюванням лише певних параметрів. Подальше опанування штучної реверберації варто здійснювати засобами програмного забезпечення (зокрема, з допомогою безплатних VST-плагінів) для цифрових звукових робочих станцій.

Ключові слова: штучна реверберація; «згорткова» реверберація; ревербераційний алгоритм; прийом використання штучної реверберації; плагін штучної реверберації

\title{
Вступ
}

Удосконалення технологій у галузі звукорежисури, поширення цифрових приладів оброблення звуку в нашій країні спонукає до активізації їхньго використання у практичній діяльності. Серед поширених технологій дослідження звуку вагоме місце посідає штучна реверберація, алгоритми якої використовуються як у приладах, так і в програмах, якими послуговуються звукорежисери. Відповідно, особливої актуальності набувають дослідження, присвячені систематизації та конкретизації прийомів штучної реверберації в сучасній звукорежисурі.

Аналіз останніх досліджень та публікацій. Реверберація різних приміщень упродовж тривалого часу була предметом багатьох наукових досліджень у галузі музичної акустики (Н. Ейрінг, Дж. Міллінгтон, У. Себін). Розроблення приладів штучної реверберації вивчалося у галузі музичної електроніки (О. Джуліус, Дж. Деторро). Використання та удосконалення нових алгоритмів реверберації розглядали у працях $з$ інформаційних технологій (Дж. Мурер, Д. Таранов). Творчо-технологічні аспекти використання штучної реверберації у звукорежисурі проаналізували Д. Гібсон (2005), Ю. Козюренко, У. Моллян (2007), Д. Мултон (2000), Б. Овінскі (1999), Е. Фернел (2010) та інші. Водночас систематизація прийомів використання штучної реверберації не була предметом актуальних наукових досліджень.

Наукова новизна полягає в уточненні класифікації та систематизації основних сучасних прийомів використання штучної реверберації, а також методичних засад опанування штучної реверберації в процесі професійної підготовки.

\footnotetext{
(C) Корякін О. О., 2021
} 


\section{Мета статті}

Мета статті полягає в систематизації основних сучасних прийомів використання реверберації у звукорежисурі.

Методологія дослідження спирається на системно-аналітичний, мистецтвознавчий та порівняльно-історичний методи. Системно-аналітичний метод використаний для систематизації досвіду штучної реверберації у звукорежисурі, мистецтвознавчий метод застосований для визначення мистецьких завдань у звукорежисурі, а порівняльно-історичний — для конкретизації місця штучної реверберації в історичній ретроспективі та взаємозв'язку зі зміною концепцій побудови простору музичних творів.

\section{Виклад матеріалу дослідження}

Розвиток технологій у сфері звукорежисури суттєво вплинув на розширення доступних прийомів та засобів оброблення звуку як в умовах концертної звукорежисури, так і у звукозаписі. Серед нових можливостей у сучасній цифровій звукорежисурі — розроблення новітніх технологій штучної реверберації. Зміст поняття «реверберація» - акустичний процес збереження звучання після закінчення звукового імпульсу або коливання завдяки віддзеркаленню звукових хвиль від поверхонь. Отже, «природна» реверберація функціонує в середовищі, у якому наявні поверхні, від яких звукові хвилі можуть відбиватися. У процесі звукозапису в концертній залі, побудованій за акустично-розрахованим проєктом і оздобленій відповідними матеріалами, такі відбивання позитивно впливають на записане звучання. Іноді (коли саме такий ефект і потрібен на записі) у сучасних умовах використовується запис із «природною» реверберацією концертної зали. Коли потрібно розташувати звукові об'єкти в різних віртуальних звукових просторах, реалізовувати інші творчі завдання в процесі зведення або мікшування, то економічно недоцільно за сучасних умов здійснювати запис кожного в певній концертній залі $з$ необхідними ревербераційними характеристиками. Із середини минулого століття здебільшого використовується саме штучна реверберація, адже набагато простіше отримати звучання 3 мінімальною реверберацією (або взагалі без неї) і вже потім з допомогою штучного ревербератора зробити його «живішим», ніж домогтися належного рівня підготовки приміщення чи здійснити звукозапис у такому приміщенні. Відповідно, штучна реверберація — це створена апаратним чи програмним шляхом імітація різних ревербераційних процесів (зокрема, таких, які функціонують у реальних концертних залах).

Сьогодні розроблення сучасних цифрових ревербераторів (як апаратних приладів та комп'ютерних підпрограм (плагінів) характеризується певною стагнацією, без нових досягнень у галузі ревербераційних алгоритмів (математичних моделей) (Browne, 2001). У цій сфері склалася досить суперечлива ситуація: 3 одного боку, в звукорежисурі використовуються «аналогові» прилади, виготовлені понад пів століття тому (наприклад, пружинні ревербератори в електрогітарних комбопідсилювачах), разом iз «цифровими», які функціонують як у апаратному вигляді, так і у програмному; з іншого — жоден із цих ревербераторів, які працюють на алгоритмах, розроблених у минулому столітті, не створює реверберацію, яку неможливо було б відрізнити від природної. Сучасні пошуки математичних моделей спрямовані саме на «відтворення» природної реверберації в різних приміщеннях. Серед сучасних прикладів штучної реверберації цікавим $є$ так звана «згорткова» (імпульсна) реверберація, що оперує поняттям дискретної згортки. Дискретне перетворення Фур'є згортки імпульсної характеристики фільтра і вхідної послідовності дорівнює добутку спектра вхідної послідовності й дискретного перетворення Фур'є імпульсної характеристики. «Згортка» в часовому відрізку еквівалентна помноженню у частотному відрізку. Ця властивість якраз і використовується для розроблення «згорткових» або конволюційних ревербераторів, адже пряма згортка може бути виконана як з імпульсної характеристики якогось апаратного ревербератора, так і з імпульсної характеристики, записаної в якомусь реальному приміщенні. Цей спосіб забезпечує досить правдоподібні результати й набув певного поширення з початку XXI століття. Після отримання імпульсних характеристик слід створити у визначеній смузі частот імпульсний сигнал, подібний функції Дірака ( $\delta$-імпульс), і залучити його до випробуваної системи і зафіксувати вихідний сигнал. Отриманий відгук і буде імпульсною характеристикою цієї системи (Browne, 2001). Підставляючи значення відліків отриманої імпульсної характеристики у формулу дискретної згортки, можна дістати точну імітацію властивостей обраної системи (за умови лінійності цієї системи). Сучасні методи отримання імпульсних відгуків приміщень використовують метод деконволюції (інверсної фільтрації) — створення імпульсного відгуку на основі використання спеціальних шумових послідов- 
ностей, а ковзний тон сприяє відновленню джерела як тестового сигналу. За інформацією записаного відгуку приміщення можна відфільтрувати гармонійні спотворення, адже вони будуть завжди розміщуватися на частотах вище тестового сигналу, а реверберація - нижче (через зростання частоти за часом). Крім того, для поліпшення співвідношення сигнал / шум можна збільшити амплітуду низькочастотної частини тестового сигналу і врахувати це в процесі деконволюції. Доцільно звернути увагу на те, що сучасні обчислювальні засоби здійснюють цю процедуру з винятковою точністю, що здебільшого і забезпечує відповідність звучання такої реверберації, наприклад, параметрам того приміщення, імпульсну характеристику якого вона імітує. Водночас кількість операцій множення і додавання значно зросте. Наприклад, для згортання сигналу завдовжки 1 с зі стандартною імпульсною характеристикою приміщення завдовжки 2 с і частоті дискретизації 44.1 кГц, кількість операцій множення / складання становить приблизно $3,89 \times 10^{9}$, а в сучасних студійних умовах оперують сигналами з частотою дискретизації 192 кГц і вище, відповідно, використання прямої згортки є неможливою за необхідності оброблення сигналу в реальному часі. Для розв'язання завдання прискорення та спрощення цього процесу у блоках використовується згортка в частотній частині 3 допомогою швидкого перетворення Фур' $\epsilon$. Застосування згаданого алгоритму зменшує обсяг обчислень і обробляє сигнали за часом, близьким до реального. Впровадження такої моделі реверберації сприяло появі апаратних та програмних «згорткових» ревербераторів із високою вартістю, але низьким рівнем варіабельності (з майже незмінними параметрами). Окрім того, на початкових етапах розроблення цієї технології у ній також наявні недоліки:

1) імпульсна характеристика відповідає тільки одному варіанту розміщення джерела звуку і слухача - очевидно, що неприродність звучання буде помітна для просторово розподілених уявних («віртуальних») джерел звукового сигналу, наприклад, ударної установки або хору;

2) уявне приміщення трактується як стаціонарна, інваріантна система, що практично неможливо;

3) труднощі створення бібліотек імпульсних характеристик;

4) найдосконаліші моделі класичних алгоритмічних ревербераторів (наприклад, такі як «Lexicon 480L») не поступаються «згортковим».

Водночас можливість використати згортки кращих концертних зал або найкращих ревербераторів у звукорежисурі розглядається як значна перевага «згорткової» реверберації. Окрім того, на сучасному етапі у згорткових ревербераторах можливо видозмінювати наявні імпульси для досягнення потрібного звучання реверберації. Найпростішою модифікацією, що зменшує час реверберації, є вкорочення імпульсу, складнішою — його «розтягування» («stretching»). Значна кількість сучасних ревербераторів варіюють відносний рівень ранніх і пізніх відбивань, а також затримання ранніх. Вважається, що для вдалої реверберації перші ранні відбивання мають приходити до слухача через 15-20 мілісекунд після прямого звуку, а сумарна потужність ранніх відбивань (в діапазоні 15-50 мілісекунд) має складати приблизно 6 дБ від потужності прямого сигналу.

Фільтрація імпульсу впливає на тембр реверберації. У загальному випадку фільтрація залежить від часу: застосовуючи до різних частотних смуг імпульсу амплітудні огинаючі, можна змінити швидкість загасання (ступінь демпфування) на різних частотах.

Важливим параметром реверберації є щільність відбивань у часі разом із випадковою всеспрямованістю їхнього приходу. Цей параметр також називається дифузністю реверберації. Для збільшення щільності можна додати до наявного імпульсу штучно модельовані відбивання або продублювати всі відбивання імпульсу з певною фільтрацією.

Інший важливий параметр - частка бічних відбивань («латеральність»). Якщо відбивання приходять 3 того ж просторового напрямку, що і прямий звук, то вони можуть спотворювати спектр звуку і вмикати «гребінчасту фільтрацію» («comb filtering»). Відбивання, які незалежно приходять 3 бічних напрямків, навпаки підвищують природність звучання, збільшуючи ефект «обволікання» («envelopment») акустичним середовищем. Застосовують також звукорежисерський прийом, коли під час панорамування прямого сигналу в одну частину стереобази, штучна реверберація панорамується в іншу.

Реверберація реальних приміщень практично лінійна, оскільки розміри приміщення не змінюються, відповідно вона може бути досить точно описана згортком із відповідним імпульсом. Однак у разі заповнення зали глядачами може з'явитися певна випадковість параметрів реверберації в часі. Такої випадковості можна домогтися, змінюючи параметри імпульсу в часі або нелінійно обробляючи отриману штучну реверберацію. Можна застосувати випадкові зміни рівня, динамічну обробку або навіть модуляцію частоти. Не всі нелінійні модифікації будуть звучати натурально, але значна їхня частина може використовуватися як додаткові виражальні засоби або спецефекти у звукорежисурі. Наприклад, модуляцію реверберації за висотою не можна застосовувати для записів роялю, адже це темперований 
музичний інструмент, без модуляцій і вібрато. Однак той же прийом у низці випадків добре «прозвучить», якщо його застосувати до каналу вокалу або групи струнних.

Очевидно, що звучання «згорткових» ревербераторів визначається насамперед завантаженими в них імпульсами (приміщень або ревербераторів) і їхніми засобами з модифікації цих імпульсів, а алгоритм «застосування» реверберації в них використовується практично один і той же.

Відповідно, виникає необхідність проаналізувати основні прийоми використання штучної реверберації в сучасній звукорежисурі. Передусім, необхідно умовно розмежувати прийоми, які походять із концертної індустрії і використовуються саме у звукорежисурі в режимі реального часу, а також прийоми, які використовуються в процесі зведення звукозаписів. Сучасні цифрові технології дають змогу використовувати у концертній звукорежисурі такі ефекти реверберації, які раніше потребували значного часу на розрахунок і могли бути використані лише у процесі зведення звукозапису. Окрім того, прийоми використання штучної реверберації змінювалися історично, що було пов'язане, передусім, з розвитком технологій та запровадженням у виробництво відповідних приладів (середина минулого століття), розробленням та впровадженням ревербераційних алгоритмів (остання чверть минулого століття), а також удосконаленням програмного забезпечення та зростанням обчислювальних можливостей комп’ютерної техніки (початок XXI ст.).

Технологічні та стильові аспекти використання різних видів штучної реверберації корелюють зі зміною «статусу» виконавців у історичній ретроспективі. 3 початку 60 -х років виконавці у звуковому просторі абстрагувалися від слухачів і були для них майже «недосяжними». Цей процес додатково підкреслювався використанням реверберації у значних просторах («Chamber»), але поступове зниження вартості технологій у галузі звукорежисури та їхній активний розвиток і поширення посприяли проведенню звукозапису музичних творів багатьох виконавців. Відомі співаки, хоча набувають популярності, але наближаються до слухача. Підкреслюється цей факт використанням листової реверберації з помітно меншим часом («Plate»). Подальша еволюція музичної індустрії, поширення нових мультимедійних технологій (поява музичного телебачення) знову модифікує «статус» виконавців: слухач опиняється ніби не лише прямо перед виконавцями, а ніби між ними, що підкреслюється реверберацією дуже малого простору («Room»), причому як спецефект використовується також і дуже «довга» реверберація, однак переважає саме коротка.

Доцільно схарактеризувати основні прийоми використання штучної реверберації в сучасній звукорежисурі.

1. Використання реверберації для створення звукової перспективи. Штучна реверберація (одного або різних видів) додається до звукових об'єктів. Ще в умовах «аналогової» звукорежисури започаткували використання кількох різновидів реверберації, детермінованих часом реверберації: 1) «room»«коротка» реверберація для створення ближнього плану; 2) «рlate» - ефект листової реверберації для створення середнього плану; 3) «hall» — «довга» реверберація для створення дальнього плану. У середині минулого століття в концертній звукорежисурі використовувався єдиний прилад штучної реверберації, а плани створювалися різним співвідношенням обробленого й необробленого ревербератором сигналу індивідуально на кожному каналі. Основною закономірністю можна вважати: збільшення реверберації, яка використовується для конкретного звукового об'єкта, віддаляє цей об’єкт від слухача у вторинному звуковому просторі. Водночас для досягнення спільності простору, зазвичай, використовується єдиний тип «короткої» реверберації («room»), який застосовують для всіх звукових об'єктів.

2. Використання реверберації для обробки бек-вокалу. Традиційно на всіх вокальних каналах використовується обробка ревербератором. Насамперед це пов'язане з тим, що між співаком і мікрофоном відстань незначна й реальний простір навколо (навіть якщо це концертна зала) 3 таким розташуванням мікрофонів передати практично неможливо. Для соло- та бек-вокалів, зазвичай, використовується один і той самий ефект штучної реверберації, однак трапляються випадки, коли в загальному звучанні соло-вокал втрачає яскравість на фоні бек-вокалу. Використання для бек-вокалу тієї ж штучної реверберації, але з дещо більшим часом дає змогу віртуально віддалити цю партію, зберігаючи певну іiі єдність iз соло. Як правило, у поєднанні з частотним обробленням (наприклад, зменшення високочастотної складової сигналу) такий прийом особливо результативний.

3. Використання реверберації на send delay (послідовна обробка дилею ревербератором). Дилей як один із поширених приладів часової обробки сигналу створює повтори сигналу, у якому можна налаштувати кількість повторів, час між ними та їхнє «затухання». Водночас такі різкі однотипні повтори можуть погіршити сприймання інших звуків, але використання обробки дилею ревербератором (з невеликим часом) надасть повторам яскравості, а також знизить їхній вплив на «розбірливість». Окрім 
того, такий прийом «розташовує» дилей ніби в певному звуковому просторі, що позитивно впливає на звукову перспективу. Також використання штучної реверберації у поєднанні з іншими ефектами часової обробки сигналу може розглядатися як спецефект і навіть складати певну «партію» у процесі аранжування музичних творів сучасних музичних стилів (наприклад, ambient).

4. Використання реверберації для «пом'якшення» звучання деяких партій музичних інструментів. Штучна реверберація, що імітує дуже маленький простір (зазвичай, «Room») з невеликим часом, дещо «пом'якшує» звучання музичних інструментів, зокрема, таких, для яких традиційно реверберація взагалі не використовувалася (наприклад, бас-гітара). Нетривалий час реверберації робить ії малопомітною у загальному звучанні, однак, партія вже не сприймається як зовсім «суха». Варіювання часу реверберації разом із динамічним обробленням суттєво моделює сприйняття «атаки» у звучанні музичного інструмента.

5. Використання реверберації для оброблення різних однотипних сигналів. Йдеться про ситуації, коли здійснюється звукорежисура дуету вокалістів або будь-яких музичних інструментів. Схожі за змістом, але різні по суті, сигнали потребують власний підхід до оброблення штучною реверберацією. Схожі сигнали часто сильно різняться за тембром. Різна реверберація зробить такі сигнали ще контрастнішими. Наприклад, можна створити ілюзію, що два мікрофони розміщені в різному оточенні. В умовах концертного виконання різниця в обробленні сигналів має бути помітною, але не разючою, адже значні відмінності в реверберації можуть навпаки погіршити сприйняття музичного твору.

6. Використання двох ефектів реверберації для оброблення партії соло (вокалу або музичного інструмента). Штучна реверберація одного або кількох близьких між собою різновидів додається на канал соло (вокалу або музичного інструмента). Налаштування кожного з ревербераторів мають відрізнятися: встановлюється дещо інший час спаду, інтенсивність (зміни налаштувань мають бути не кардинальними, але помітними). Оброблений ревербераторами сигнал за панорамою розміщується не по центру, а дещо лівіше і правіше, потім ці оброблені сигнали обробляються сатуратором або емулятором магнітної стрічки та поєднуються між собою. Виконані дії створюють оригінальний ефект стереореверберації. Соло збереже простір у центрі, не втратить виразності, але водночас набуде необхідного об'єму і моносумісності.

7. Використання двох ефектів реверберації в обробленні різних барабанів. Ефект штучної реверберації, наприклад, для малого (робочого) барабана використовується паралельно з ревербератором на загальному каналі усієї барабанної установки — доволі поширений прийом у обробленні барабанів. Він виокремлює малий барабан на тлі всієї установки і допомагає йому стати помітнішим у загальній звуковій картині. Найдоцільніше використовувати цей прийом у роботі з акустичними ударними, в яких для робочого барабана використовуються два мікрофона — верхній і нижній. Оброблення звуку від нижнього мікрофона щільно і яскраво виділяє робочий барабан. Для реалізації цього прийому потрібно паралельно до необробленого сигналу від нижнього мікрофона робочого барабана також обробити його послідовно дилеєм із затримкою приблизно 7-15 мілісекунд, а далі - ревербератором (із незначним часом реверберації), відповідно до особливостей музичного твору. Далі, комбінуючи звук необробленого нижнього мікрофона та обробленого у різних пропорціях, важливо домогтися, щоб робочий барабан «злився» $з$ усією установкою, але здобув чіткий високочастотний акцент (від звучання струн). Цей самий прийом можна застосувати і до томів. Сигнал від мікрофонів кожного тому варто обробити окремим ревербератором, в яких варто послабити пізні відбивання і посилити ранні, потім потрібно комбінувати сигнали томів так, щоб кількість реверберації становила орієнтовно $10 \%$.

В умовах активного розвитку та удосконалення процесу професійної підготовки звукорежисерів, а також значної стильової диференціації в музичному мистецтві, очевидно, що наразі використовується чимало різних оригінальних прийомів штучної реверберації. Пошук і добір конкретних прийомів для визначеного музичного твору, засобів їхньої реалізації є результатом пошуків і досвіду кожного звукорежисера. Окрім того, досягти одного і того ж «творчого» результату у звукорежисурі можливо різними «технічними» засобами та рішеннями.

У процесі професійної підготовки використання штучної реверберації доцільно розпочинати зі знайомства $з$ основними різновидами реверберації («Room», «Plate», «Spring», «Hall» тощо) та тим, як на одному і тому ж сигналі «звучать» різні ефекти реверберації. Як звуковий матеріал для здобувачів вищої освіти краще використовувати імпульсні джерела (наприклад, поодинокі удари («shoot») барабанів), адже вони сприяють усвідомленню характеру реверберації. Згодом можна використовувати для цього власний голос. Вагомого значення набуває попередній досвід (передусім, слухацький) здобувачів освіти та їхня здатність «уявляти» звук. Відвідування заходів у спеціально спроєктованих 
для цього концертних залах формує в здобувачів освіти власні показники «оптимальної реверберації», наприклад, для музичних творів у виконанні симфонічного оркестру. Водночас прослуховування звукозаписів музичних творів певного стилю формує «референсне» звучання для конкретного музичного стилю, зокрема, і «кількість» реверберації, яка використовувалася у процесі зведення. Варіювати на початковому етапі доцільно лише основні параметри, зокрема час реверберації. На цьому етапі може бути використаний навіть «аналоговий» процесор звукових ефектів, бо в найпростіших моделях представлено основні різновиди штучної реверберації та регульований іï час. Доцільно використовувати також «вбудовані» до цифрової звукової робочої станції плагіни реверберації.

Серед безплатних VST-плагінів штучної реверберації на початковому етапі професійної підготовки можна схарактеризувати декілька доступних для опанування та широко вживаних: «Abstract Chamber», «AlgorVerb», «Valhalla Supermassive», «Classic reverb 8X», Ambient Reverb.

3-поміж складних безплатних VST-плагінів штучної реверберації на пізніших етапах професійної підготовки можна виділити такі, які дають змогу регулювати чимало параметрів реверберації й надавати звукорежисеру значну свободу творчості: «MConvolutionEZ», «Convology XT», «SIR» «Reverberate LE», «Halls Of Fame 3 Free».

В умовах сучасного розвитку інформаційних технологій і цифрового оброблення звуку доступними є різні засоби (як апаратні, так і програмні), що сприяють опануванню штучної реверберації. До більшості сучасних VST-плагінів виробники створюють навчальні відео для опанування інтерфейсом та засвоєння можливостей конкретного продукту. Їх можна розглядати як важливий і корисний засіб усвідомлення початківцями особливостей штучного ревербератора та його значення у звукорежисурі.

\section{Висновки}

Розвиток сучасних цифрових технологій у галузі звукорежисури, впровадження алгоритмів моделювання імпульсних характеристик приміщень суттєво вплинули на можливості використання штучної реверберації у звукорежисурі. У практиці оброблення звуку напрацьовано значну кількість ефективних прийомів використання штучної реверберації для реалізації різних творчих завдань звукорежисури. Історично різновиди штучної реверберації використовувалися на різних етапах розвитку звукозапису. На сучасному етапі програмне забезпечення використовує одразу декілька алгоритмів реверберації і формує оригінальні звучання у сучасній музиці. У процесі засвоєння здобувачами вищої освіти прийомів штучної реверберації варто розпочати з найпростіших ефектів реверберації, які можуть варіювати лише деякі параметри. Подальше опанування штучної реверберації доцільно здійснювати через програмне забезпечення (зокрема, безплатні VST-плагіни), яке змінює чимало показників. На завершальному етапі опанування ефектами штучної реверберації доцільно здійснювати з допомогою сучасних згорткових (конволюційних) ревербераторів. Позитивно на спроможність використання штучної реверберації впливає накопичення слухацького досвіду музичних творів як у концертних залах, так і звукозаписів.

Подальші наукові пошуки в окресленій галузі доцільно спрямувати на розроблення технологій поєднання ревербераційних алгоритмів та методики їхнього використання в сучасній звукорежисурі.

\section{References}

Browne, S. (2001). Hybrid Reverberation Algorithm Using Truncated Impulse Response Convolution and Recursive Filtering [Abstract of a Master's Research Project, University of Miami]. CiteSeerX. https://citeseerx.ist.psu.edu/ viewdoc/download?doi=10.1.1.127.67\&rep=rep1\&type=pdf

Farnell, A. (2010). Designing Sound. The MIT Press.

Gibson, D. (2005). The Art of Mixing (2 ${ }^{\text {nd }}$ ed.). PArtistpro.

Moulton, D. (2000). Total Recording. KIQ Productions.

Moylan, W. (2007). Understanding and Crafting the Mix: The Art of Recording ( $2^{\text {nd }}$ ed.). Focal Press.

Owsinski, B. (1999). The Mixing Engineer's Handbook. Artistpro. 


\section{ПРИЁМЫ ИСПОЛЬЗОВАНИЯ \\ ИСКУССТВЕННОЙ РЕВЕРБЕРАЦИИ В СОВРЕМЕННОЙ ЗВУКОРЕЖИССУРЕ \\ Кандидат педагогических наук, старший преподаватель, Сумской государственный педагогический университет имени А. С. Макаренко, \\ Сумь, Украина}

Цель статьи заключается в систематизации основных современных приемов использования реверберации в звукорежиссуре. Для реализации цели использованы методы: системно-аналитический, искусствоведческий и сравнительно-исторический. Научная новизна заключается в уточнении классификации и систематизации основных современных приемов использования искусственной реверберации, а также овладении методических основ искусственной реверберации в процессе профессиональной подготовки. Основные результаты и выводы исследования. Эволюция цифровых технологий в области звукорежиссуры, введение реверберационных алгоритмов способствовали активному использованию искусственной реверберации, в частности «свёрточной» реверберации с современным реверберационным алгоритмом. В статье рассмотрены приемы искусственной реверберации для создания звуковой перспективы; для обработки back-вокала и дилея; для «смягчения» звучания определенных партий музыкальных инструментов; для обработки различных однотипных сигналов; для обработки партии соло с двумя эффектами реверберации. Определенные разновидности искусственной реверберации использовались на различных этапах развития музыкальной индустрии. Современное состояние развития программного обеспечения позволяет использовать сразу несколько алгоритмов реверберации и создавать оригинальное звучание. Усвоения соискателями высшего образования приемов искусственной реверберации целесообразно начать с самых простых эффектов с незначительным варьированием определенных параметров. Дальнейшее освоение искусственной реверберации следует осуществлять с использованием средств программного обеспечения (в частности, при помощи бесплатных VST-плагинов) для цифровых звуковых рабочих станций.

Ключевые слова: искусственная реверберация; «свёрточная» реверберация; реверберационный алгоритм; прием использования искусственной реверберации; плагин искусственной реверберации

\section{TECHNIQUES FOR USING Oleksii Koriakin ARTIFICIAL REVERBERATION IN MODERN SOUND ENGINEERING PhD in Education, Senior Lecturer, A. S. Makarenko Sumy State Pedagogical University, Sumy, Ukraine}

The purpose of the article is to systematise the main modern methods of using reverberation in sound engineering. To achieve the goal, the following methods were used: systematic and analytical, art studies, comparative and historical. The scientific novelty consists in clarifying the classification and systematisation of the main modern methods of using artificial reverberation, as well as mastering the methodological foundations of artificial reverberation in the process of professional training. The main findings and conclusions of the study. The evolution of digital technologies in the field of sound engineering, the introduction of reverb algorithms contributed to the active use of artificial reverberation, in particular "convolution" reverb with the most modern reverb algorithm. The article considers artificial reverberation techniques for creating a sound perspective; for processing back vocals and delay effect; for "softening" the sound of certain parts of musical instruments; for processing various signals of the same type; for processing a solo part with two reverb effects. Certain types of artificial reverberation were used at different stages of the music industry development. The current state of software development makes it possible to use several reverberation algorithms at once and create an original sound. It is advisable for higher education students to start learning the artificial reverberation techniques with the simplest effects with a slight variation of only certain parameters. Further mastering of artificial reverberation should be carried out using software tools (in particular, free VST plug-ins) for digital audio workstations.

Keywords: artificial reverberation; "convolution" reverberation; reverberation algorithm; artificial reverberation technique; artificial reverberation plug-in 